\title{
APROXIMAÇÕES À COMPREENSÃo DA SEUS POSSÍVEIS VÍNCULOS COM A FILOSOFIA ${ }^{1}$
}

Jorge Ordóñez Burgos²

\section{Resumo}

O pensamento dos povos da Antiguidade é composto de linguagens, sistemas de valores e proposições que escapam não só aos convencionalismos linguísticos atuais, mas também se distanciam das categorias próprias da filosofia, da religião e até mesmo da mitologia. Um caso ilustrativo é a ( $h k 3)$ egípcia, cuja tradução nas línguas contemporâneas é magia, magic, Zauber e Magie; nessa tradução, vincula-se uma série de conotações próprias da mentalidade judaico-cristã e evolucionista. Uma simples magia, fruto do homem crédulo, supersticioso e detentor de uma mente preguiçosa. Tal simplificação, entretanto, não se preocupa em estudar aspectos de grande relevância como o processo de transmissão que a palavra sofreu ao longo dos séculos, omitindo o papel desempenhado pela magia persa no interior da reflexão de filósofos, historiadores e poetas da Hélade. A ( $h k 3)$ foi uma forma de conceber o universo que não pode se limitar somente a crenças pseudo-religiosas; foi uma sofisticada estrutura para entender as coisas que, simplesmente, não conhecemos. Este artigo é um convite a uma revisão dos produtos culturais de séculos distantes, sem perder de vista que a incompreensão não se localiza exclusivamente nesse distante, mas nas próprias entranhas do nosso tempo.

\section{Palavras-chave}

Filosofia antiga; pensamento egípcio; magia.

\footnotetext{
1 Tradução de Estefanía Barnabé Sánchez.

2 Professor Doutor, Universidad Autónoma de Ciudad Juárez - Ciudad Juárez, México. email: vonschlegel@gmail.com
} 


\section{Resumen}

El pensamiento de los pueblos de la Antigüedad se compuso de lenguajes, sistemas de valores y planteamientos que escapan no sólo a los convencionalismos lingüísticos actuales, también resultan ajenos a las categorías propias de la filosofía, la religión y la mitología misma. Un caso revelador es la ( $h k 3$ )egipcia, traducida a lenguas contemporáneas como magia, magic, Zauber o Magie; en dicho traslado, se le adhiere una serie de connotaciones propias de la mentalidad judeocristiana y evolucionista. Una magia sin más, producto del hombre crédulo, perezoso de mente y supersticioso. Sin embargo, tal reducción no se preocupa en estudiar aspectos de gran trascendencia como el proceso de transmisión que la palabra sufrió al cabo de los siglos, omitiendo el papel que jugó la magia persa dentro de la reflexión de filósofos, historiadores y poetas de la Hélade. La ( $h k 3)$ fue una manera de concebir el universo que no puede reducirse sólo a creencias pseudoreligiosas, fue una sofisticada estructura para entender las cosas que, sencillamente, desconocemos. El presente artículo es una invitación a revisar los productos culturales de siglos lejanos, sin perder de vista que la incomprensión no se da exclusivamente con lo distante, sino en las entrañas mismas de nuestro tiempo.

\section{Palabras clave}

Filosofia antigua; pensamiento egipcio; magia. 


\section{A tradução cultural}

O ser humano é inquieto, possui uma curiosidade expansiva cujos limites se redefinem constantemente. É um animal que gosta de buscar aqui e ali, em si mesmo e nos demais; especula sobre o futuro, revisa o presente a partir de diversos anglos e escava o passado com vigor quase infatigável. É necessário muito mais que entusiasmo para sustentar tão extenuante vocação. Sair pelo mundo com atitude de descobridor exige saber o que se está buscando tanto ao penetrar as profundezas da natureza como na complexidade das civilizações. É neste segundo contexto que quero colocar minha atenção. Para o presente estudo, será observada uma prática muito arraigada ao antigo Egito, a $1 h k 3)$, conhecida em idiomas contemporâneos como "magia" Desde a época dos antigos gregos, correram rios de tinta para intentar captar seu significado mais profundo. Em certos momentos foi abordada com admiração, talvez até com a devoção que se trata a Verdade revelada. Em outros, com desprezo e entendendo-a claramente como superstição máxima de irracionalidade, pertencente a um estamento evolutivo inferior a outros dos quais originaram a ciência e a "razão". A partir das condições descritas, surgem inquietudes sobre o tratamento que recebem esta e outras manifestações culturais. Que ferramentas conceituais dispomos para revisar uma atividade tão importante para os egípcios? Pretende-se conhecer o passado para justificar a forma de proceder no presente? Ao voltar os olhos para a Antiguidade, dispõe-se dos meios para entender as coisas em seu nicho humano original e as julgar com certo ar de superioridade?

Em nosso artigo usaremos a expressão tradução cultural para se referir ao processo através do qual um leitor, valendo-se do marco referencial próprio, estabelece vínculos entre práticas mais ou menos equivalentes desenvolvidas por civilizações diferentes. Por exemplo, alguns processos curativos seguidos por povos indígenas são nomeados por nós como "curandeirismo", "medicina popular", "medicina alternativa" ou "tradicional". Ao chamá-las assim se deixa claro que seus tratamentos não estão plenamente apegados às ciências e aos métodos racionais aprovados por nós; além do mais, pode-se ver que nossas categorias não coincidem com as suas, sendo insuficientes para captar sua mentalidade e propósitos. Poderia se pensar que a sabedoria com que se denigre o irracional ou pseudocientífico é um signo de superioridade e só assinala as carências do alheio, porém, exibe também os vazios de nossa estrutura basilar. Tudo depende do Ângulo a partir do qual se vejam as coisas. Seja o que seja aquilo que os outros fazem, não 
alcançamos assimilá-lo de todo. A tradução é uma versão das coisas que nunca é perfeita e certeira, contudo, não contamos com outro recurso para ter certa proximidade com o outro.

No meio da disparidade, faz-se necessário construir pontes para saltar obstáculos. A ponte é um caminho que se erige sobre falésias, rios ou córregos, deixando a geografia debaixo de si. Águas turvas e profundas são vistas de distantes alturas, andar sobre elas proporciona um sentimento de superioridade e seguridade, às vezes ilusório. Concretiza-se o caminho de ida, talvez o da volta, mas, é muito que se passa por alto. Ao completar a primeira parte do caminho, consegue-se chegar a um destino que poderia ser até inteligível. Se existisse uma máquina do tempo para transportar-se a uma ágora grega ou a um templo egípcio, possivelmente o choque cultural seria tão forte que se chegaria à conclusão de estar frente a uma miragem ou que a realidade se equivoca. Egito e Hélade em cores, aromas e sons vivos seriam discordantes com as reconstruções feitas a partir de tratados antigos, tocados por muitas mãos, por vasilhas vazias exibidas em vitrines e pálidos templos meio destruídos. Mesmo contando com os meios para observar em primeira mão a dinâmica de um passado tão distante, seria impossível compreender em plenitude o palpitar da vida dos antigos. É nos exigido desenvolver categorias-ponte para conectarmos de alguma maneira com eles, contudo, apesar das facilidades conseguidas, existem aspectos que passam, para dizê-lo em uma palavra, desapercebidos. As inúmeras limitações que temos para nos aproximarmos da Antiguidade não seriam resolvidas com abundante evidencia material e empírica; a compreensão dos antigos tem muito a ver com a atitude seguida para lê-los em seu habitat.

A noção de tempo que os antigos tinham faz com que as diferenças entre nós se agravem. Cidades com escassa densidade populacional - comparada com as atual - abrigavam comunidades concentradas em atividades diárias distintas das nossas. $\mathrm{O}$ fato de se locomover de um lugar a outro dentro da mesma cidade era um processo simples; não acontecia o mesmo com as viagens para outra cidade ou país, empreitada em que não poucos deixaram a vida ao enfrentar inúmeras dificuldades como epidemias, inclemências do tempo ou o assalto de piratas e bandidos, que formavam parte da paisagem. O deslocamento redundava na noção cotidiana e teórica de espaço e tempo. Para nós é difícil deixar de ver com naturalidade a possibilidade de fazer viagens transcontinentais em poucas horas, proeza divina para os arcaicos. Nesse contexto, diversas práticas culturais como o comércio, a religião, a guerra, a alimentação ou a poupança, adquiriam outras notas e sentidos diferentes dos nossos. A noção de espaço, sem maiores pretensões e 
elucubrações filosóficas, era então, como hoje, moldura e ancora através da qual a cultura florescia. A irrupção na Antiguidade, num médio tão estranho ao próprio se completa, em principio, a partir da omissão de detalhes tão simples e comuns que compõem a cotidianidade. Ao procurar outros aspectos mais sofisticados, e.gr. os grandes ideais, abstrações ou os desenvolvimentos tecnológicos, deixam-se de lado os elementos "irrelevantes" que determinam ideias, crenças e formas de aproximação ao mundo, enraizadas no imediato e tangível.

\section{Perfilando la traducción cultural: los bemoles del presente}

Mesmo a compreensão do mundo contemporâneo oferece inúmeras dificuldades. Tomemos por exemplo o tema do esporte olímpico a nível mundial. A preparação de atletas para algumas economias africanas não tem paralelo à seguida nos Estados Unidos ou na China. $\mathrm{O}$ significado que o esporte tem em cada uma de estas nações nos leva, de fato, até cenários incompatíveis entre si. Porém, a cada quatro anos falamos do esporte olímpico como vínculo de união e boa vontade. A realidade tangível nos diz que, em cada sociedade, o papel do atleta e do esporte é modificado dramaticamente. Enquanto em algumas economias é a figura central para a qual convergem os mais novos avanços científicos, tecnológicos e educativos (como o sofisticado desenho de roupa esportiva, elaborada com materiais ultraligeiros e resultado de investigações multimilionárias exportadas ao planeta todo - ou a exploração do talento de brilhantes engenheiros que se coloca na construção de dardos, trenós, remos e flechas). Contrariamente, nos países do terceiro mundo, é o reflexo dos privilégios de certas elites que são beneficiadas com dádivas grosseiras e insultantes. Regimes colados com alfinetes enviam delegações de esportistas sem nível para competir com grandes luminares. Pareceria que, ao participar em encontros mundiais, automaticamente se adquirisse legitimação da comunidade internacional. Então, que significa o esporte olímpico, no nosso mundo contemporâneo? Não é uma pergunta que possa ser respondida com facilidade, pois para fazê-lo devemos recorrer a um processo de tradução cultural. Um exercício árduo que exige ter um grande conhecimento das circunstancias atuais e históricas que rodeiam os países do orbe.

Em processos mais complexos, caracterizados pela interiorização de ideias e sentimentos, é ainda mais difícil unificar critérios. Por exemplo, a convivência pacífica de diferentes religiões tremula como estandarte da 
tolerância em nossos dias. Vemos patriarcas, pastores, rabinos e cardeais juntarem-se para orar, protagonizando uma dança da humanidade civilizada onde, porém, cabe a pergunta, para quem ou que estão orando? Este é outro campo onde a tradução cultural pode oferecer certa ajuda. Quando é decretado que existe respeito a todas as crenças religiosas dos cidadãos de um país, é simples imaginar em abstrato a imposição de dignidade às crenças, ritos e ideias sobre o sagrado. Não obstante, com grande frequência se desqualificam práticas colocando-as no terreno do "primitivo" ou "popular". No melhor dos casos, esta etiqueta significa que quem abraça tal o qual esquema de crenças são ignorantes e estão à margem de uma teologia racional bem elaborada. Ou seja, de um aparelho fundador que articule conceitualmente uma doutrina, uma liturgia ou uma soteriologia em particular. Por isso, procissões, adoração de santos e imagens - não autorizadas por uma jerarquia ilustrada-, a crença em milagres ou a aparição de seres divinos, são tirados do terreno das crenças pessoais do fiel para ser objeto de auscultação minuciosa. O expert determinará se são produto da superstição ou da fé racional e higiênica. Quando é um rito a magia, e quando o exercício de uma clara revelação divina? Quando a teologia é tal, e quando se converte em fundamentalismo? A tolerância religiosa, - concessão da mesma dignidade às praticas religiosas alheias que às próprias -, se dilui no preciso momento em que se tenta avaliar o alheio, ou convencê-lo da própria fé. É quando se minimiza o diferente para sobrepor algo melhor ao critério do evangelizador-árbitro.

Que é, em sentido amplo, a religião, a fé? Práticas quotidianas que envolvem todos os aspetos da vida do individuo? Um arsenal de respostas a todas as possíveis perguntas que possam sair ao passo do homem? Uma via sobrenatural para explicar fatos naturais? É possível opinar sobre crenças pessoais do homem levando-as a uma linguagem antropológica-psicológica que não sempre consegue entrar na natureza da fé? Em encruzilhadas como estas é quando a tradução cultural pode brindar certas contribuições. Um esforço mais ou menos completo de compreensão; um processo de interconexão e exploração, sem duvida, mas também, para dizer a verdade, uma simplificação que sempre deixa resíduos no caminho. Ao incursionar em estudos sobre religiões é importante aceitar que, de origem, é falida a assimilação plena da fé alheia, por superficial que seja. A banalidade foge de ser captada plenamente. Gostaria de enfatizar que aproximar-se das religiões vivas e incrustradas no mesmo âmbito social significa um desafio importante para o pesquisador. Que pode esperar-se de crenças tão distantes como as dos egípcios? Fazer historia das religiões é complicado, de maneira 
alguma ocioso, mas é um esforço que resulta incompleto sempre, assim são os limites do saber humano. Não é exclusivo de este campo, nos estudos culturais existem fronteiras infranqueáveis que devem ser assumidas mais do que negadas ou minimizadas.

Sucede algo similar com as investigações comparativas da filosofia, detectando excessos preocupantes nos últimos cem anos; no passado e no presente, na América e na Europa, uma tradição anula a outra, considerando que está fincada em falácias ou é fútil. Boa parte da historia da filosofia do século XX se desenvolveu através da difamação de umas escolas a outras. A reflexão se concentrava em elaborar argumentos que colocassem contra a parede o oponente, mais do que em construir um pensamento original. Hoje em dia é complicado fazer coincidir no mesmo planeta e momento a filosofia geopolítica contemporânea dos Estados Unidos e algumas variantes do neokantinianismo europeu atual. A primeira, criada por estadistas e politólogos, a segunda, erudita e escorada por recursos poderosos tomados da filologia, da psicanálise, de leituras tardias do marxismo e do neotomismo. Caricaturizando a pluralidade de pensamento, chamamos ambas de "filosofia" sem precisar que se faz uma abstração ou simplificação, sem atender as variantes que qualquer pratica humana tem por natureza. A questão é mais profunda, dado que o significado social e prático das reflexões do norte-americano partem de uma base que comparte alguns elementos, do seu correlato europeu dos últimos dois séculos, em essência, renuncia a cingir-se a métodos "especulativos estéreis", segundo seus propósitos utilitários. É uma filosofia cujos eixos são a ofensiva comercial mundial, o manuseio estratégico de médios de comunicação além de abertura de novos mercados que validarão o xadrez político jogado de maneira correta. Um filosofar que, simplesmente, passa dos gregos, dos medievais e da Escola de Frankfurt. Por sua vez, os europeus qualificaram de filosofastros aos americanos por não serem partícipes $d a$ filosofia Nesse contexto, o estudo da Antiguidade não é o único meio que oferece problemas de compreensão cultural. Se as religiões e a filosofia do Ocidente contemporâneo é difícil abordá-las sem deparar-se com problemas de incompatibilidade tem-se autoridade para julgar aos antigos, menosprezando sua forma de pensar e crer? Aponto os paradoxos para compreender as religiões e a filosofia porque é nesse contexto no qual poderia enquadrar-se a para estuda-la. É impossível conseguir integridade absoluta nos métodos de investigação, talvez a atitude mais racional a seguir consistiria em aceitar as próprias inconsistências? 
Gostaria de propor aqui alguns elementos essenciais que servirão para ter uma aproximação mínima ao pensamento que não é próprio.

I) Expor a ideia de "outredade 3 " sob a convicção que se 'dignifica' ao outro é, mais do que tudo, adotar uma postura um tanto soberba. Tudo aquilo que 'não sou eu' existe com independência de mim - sem importar como eu o detrate ou enalteça - e oferecerá certa resistência a ser entendido. A primeira barreira se da em mim, pois, em certa medida, sempre tentarei achegar o desconhecido, o 'não próprio' ao universo pessoal. Por mais objetividade que pretenda conseguir, as vivencias, as crenças, ideias e costumes do outro serão acessíveis mediante as categorias de quem observa. A outredade não só se da com o habitante de terras longínquas, possuidor de regras de convivência diferentes às minhas, também com um vizinho ou membro da minha família, quem, apesar de ter marcos referenciais mais ou menos próximos, elaborou um universo autônomo distinto ao meu. Ou seja, terá um código de tradução diferente ao que tenho.

II) É verdade que, ao analisar outras civilizações, fazemos uma valoração das mesmas. Mas é preciso eliminar qualificativos como "livre", "evoluído", "pagão", "cientifico", "tecnológico", "popula", "précientífico", "irracional", "mítico", "supersticioso", "democrático" e todos aqueles que contenham uma forte carga axiológica para nós. Adjetivos que comprometam a concepção dos outros, ao ponto de denegri-los considerando-os num estamento inferior ao nosso. Rejeitaríamos que uns confucianos jogaram fora milênios de filosofia ocidental porque nossos pensadores não contemplam o termo 善 $(j e n / r e n)^{4}$ como parte substancial da ética e da cosmologia. Que nos

\footnotetext{
${ }^{3}$ Nota da Tradutora: a palavra espanhola, no original, é "otredad". Escolhemos traduzi-la por "outredade" com base em uma obra de Paulo Freire, Pedagogia da autonomia (São Paulo: Paz e Terra, 1996), onde diz: "A assunção de nós mesmos não significa a exclusão dos outros. É a "outredade" do 'não eu', ou do tu, que me faz assumir a radicalidade do meu eu" (p.19).

4 Simon Leys, no seu comentário às Analectas (4.1) de Confúcio observa sobre esta palavra: “...a virtude suprema, [é] com frequência traduzida como "bondade", "benevolência" ou "virtude". A pessoa que a pratica é "o homem bom", "o homem virtuoso", "o homem plenamente humano". Normalmente traduzo este termo por "humanidade", mas em algumas ocasiões utilizo "bondade"... Não preciso dizer que todas estas traduções tem sido irremediavelmente inadequadas; o pior erro seria descrever a Confúcio com as pálidas cores de uma espécie de filantropo benigno ou de trabalhador social bemintencionado. Nenhuma outra imagem poderia estar mais longe da realidade histórica. Para Confúcio, ren, a plenitude da humanidade, é verdadeiramente um absoluto de inexpressável e ofuscante esplendor; este absoluto é o que exige heroicidades a cada
} 
justifica, então, a desacreditar esquemas de pensamento que não se sujeitam à "razão"? É impossível se desfazer inteiramente de préjuízos, pré-noções e categorias culturais, mas ajudaria a evitar o distanciamento abster-se de usar, na maior medida possível, dos adjetivos assinalados. Assumir uma atitude de esta natureza poderia asfaltar o caminho até outras culturas.

III) Por estratégia metodologia, assumimos que os "demais", entenda-se aqui os antigos, são muito diferentes a nós. Podem sê-lo, mas, dentro do processo de tradução cultural é importante achar aspetos que sejam comuns. A cotidianidade pode ser uma fonte significativa de vinculação. Relacionar-se com alguns aspetos da vida diária de povos tão distantes é um grande esforço para o investigador; a subsistência, a alimentação, a convivência ou a maneira em que a morte se aceita são áreas nas quais pode haver coincidências conosco. A partir dali poderia se iniciar a tradução cultural. É inevitável comentar anacronismos, mas não podemos esquecer que o que se busca é uma aproximação a sociedades que estiveram vivas no seu momento.

IV) No caso concreto do pensamento e das diferentes denominações que os povos lhe dão (filosofia, sabedoria, reflexão, memória ou iluminação) é preciso compreender que sempre estaremos sujeitos a um marco regulatório. Seja uma tradição ritual, uma religião, o estado, a magia ou a oralidade, note-se que advém do material conceitual que disponho para expressar-me. $O$ que não significa que as meditações conseguidas em âmbitos diferentes não possam brindar uma contribuição relevante para nosso filosofar.

V) É necessário assumir que a filosofia ocidental comtemporânea também está subscrita a marcos que, dentro das sociedades vivas resultam ser o mais viável e óbvio. Nossa filosofia é racional, remetendo-nos ao complexo e ambíguo universo da razão ocidental. É científica, democrática, humana, aberta, tolerante... cada adjetivo abre espaços que não são unanimemente aceitos hoje por todos os habitantes deste planeta.

pessoa, mas permanece próximo e à mão na vida cotidiana; ninguém o possui, mas informa todos nossos atos ainda que nunca possa ser totalmente captado, está constantemente se revelando em suas diversas manifestações." (1998: 203-204). O trabalho de Paul Lüth, Die japanische Philosophie (Tübingen: J.C.B. Mohr, 1944), pode brindar-nos com mais elementos para nos aproximarmos da problemática de outras filosofias cujos refetentes e interesses não tem paralelo com as nossas. 
VI) Como exercício historiográfico, é conveniente imaginar como seriam estudadas nossas civilizações em alguns milênios. Talvez nossos colegas do futuro - eu uso a tradução cultural para invocá-los nem sequer considerem importante o tema da tecnologia, a ciência, a democracia ou o cristianismo. Possivelmente, nossas sociedades terão outros atrativos para eles, outros, ocultos no mais profundo de nossa vida cotidiana, velados aos nossos olhos.

VII) No contexto especifico da Antiguidade, é importante assumir que enfrentamos um mundo em movimento constante, cuja dinâmica provavelmente não alcançamos, sequer dimensionamos. Existem tantos povos que passam desapercebidos para nós, e outros que conhecemos por referências fugazes, que tão irresponsável quanto arriscado elaborar juízos categóricos sobre eles. Por exemplo, a Etrúria, encravada na Europa "familiar", próxima a romanos e gregos, constitui um duro golpe para nossa arqueologia. Uma civilização quase tangível, mas distante e enigmática nos recorda que a Europa antiga a esboçamos em sombras. Determina-se com rapidez que as sociedades fora do âmbito greco-romano foram sociedades primitivas e carentes de maior complexidade. Celtas, jutos, eslavos, iberos, bretões, citas e germanos são minimizados a aldeias governadas por feiticeiros. É incorreto que milênios sejam julgados sob os fechados parâmetros com os quais analisamos de Grécia e de Roma.

Dito isso, iniciamos nossa tentativa de traduzir a ideia de

\section{A conformação do termo "magia": um problema de tradução cultural}

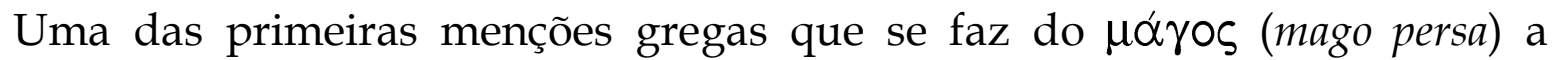
encontramos na História do velho Heródoto. Sua referência não se reduz a uma passagem única, mas é em I, 132,2 onde está definido com maior detalhe, isto é, uma espécie de sacerdote oficiante pertencente a uma das etnias que compunham o império persa ${ }^{5}$. Em III, 70-79 se descrevem as

\footnotetext{
${ }^{5}$ Walter Burkert comenta sobre o termo dy[üıcc (maguš) dentro do contexto persa: “...o termo "mago" está praticamente ausente no Avesta [aparece só no Yasna 65,7]. Mas uma documentação autentica sobre os magos como funcionários religiosos existe nas tabuinhas elamitas de Persépolis da época de Dario [Koch, 1992: 279 s]... Da zona fronteiriça entre helenismo e iranismo, ou seja, da

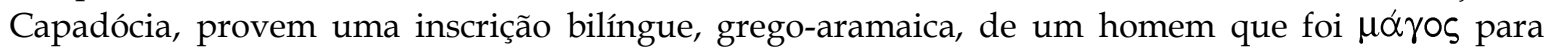

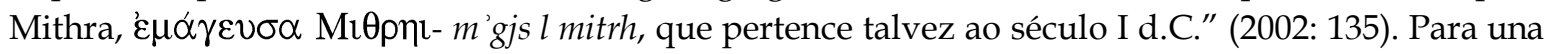


intrigas e tensões políticas que protagonizaram alguns magos, sendo enquadrados nas mais altas esferas do poder imperial, adicionando um elemento mundano ao religioso para arredondar seu perfil. Seguindo a lógica aplicada com Pitágoras como criador da palavra filosofia a partir de se identificar como filósofo, a $\mu \alpha \gamma \varepsilon i ́ \alpha$ seriam as práticas, crenças e ideias próprias dos magos persas ${ }^{6}$. É importante lembrar que a exposição de Heródoto sobre cultos religiosos estrangeiros não sempre dissipa dúvidas, pelo contrario, deixa com inquietude ao respeito de estarmos ante um exercício de pedagogia consistente em helenizar o forâneo com o objetivo de fazê-lo mais compreensível para o público; se é uma redução de crenças e divindades que não tem a estatura do grego, ou o desenvolvimento de uma tradução cultural através do qual muita coisa ficou no caminho, mas que, porém, não pode ser concretizada de outra maneira que não seja por meio da linguagem que Heródoto e sua gente falavam7 ${ }^{7}$. A que exatamente estavase referindo o de Halicarnasso quando afirmava que os magos entoavam uma $\theta \varepsilon$ covoví $\eta$ durante os sacrifícios (I, 132,2)? Era, em realidade, uma peça que falava da origem dos deuses iranianos, ou eram ensalmos, conjuros, talvez até um gênero que não tem paralelo dentro de nossas tradições como acontece, por exemplo, com os hinos sumérios? O que sim podemos concluir é que Heródoto tinha uma boa opinião dos persas e suas instituições, como

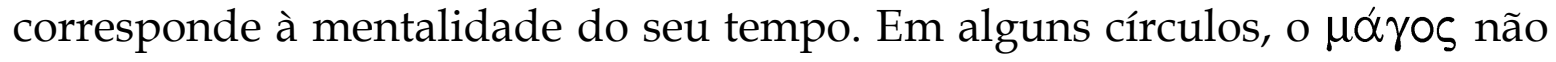
era um personagem nefasto; o sentido do termo mudou, passando de ser quase um gentílico bárbaro a uma maneira de avocar os sacerdotes gregos relacionados com os mistérios e as iniciações.

Assim o explica Raquel Martín Hernández (2008: 805) tomando como base um trecho do Papiro Derveni (Col. VI) e um fragmento de Heráclito (Clem. Al. Prot. 2.22.2) $)^{8}$ :

revisão histórica do termo maguš, Cf. o artigo "Magi" de Muhammad A. Dandamayev (2012), disponível em http://www.iranicaonline.org/articles/magi.

${ }^{6}$ De acordo com SUDA x, 9, um artigo dedicado a Janto, diz que ele escreveu uma história de Lidia em 4 livros $(\Lambda v \delta i \alpha \kappa \alpha)$. Guido Schepens, no seu comentário ao FGrH 765, menciona a possibilidade de que o catálogo de obras de Janto fosse composto, além do texto citado, de um estudo sobre Empédocles e uma $M \alpha \gamma l \kappa \alpha ́$. Sobre isto há polemica, dado que alguns estudiosos especulam com

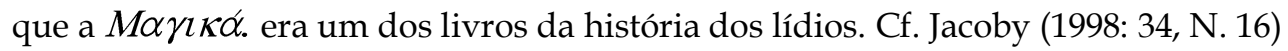

${ }^{7}$ Considero que a interpretação de Momigliano (1999: 206- 210) é a mais acertada. Ele faz uma leitura da História de Heródoto como um exercício de compreensão dos persas.

${ }^{8}$ Cabe citar o comentário de Calvo Martínez (2007: 306), onde afirma que é o primeiro texto grego que menciona o termo $\mu \alpha ́ \alpha \gamma o r$ mas só conectado com as tradições iniciáticas, presumivelmente dionisíacas. 
...no es necesario pensar que los expertos que realizan dichos ritos sean profesionales venidos de fuera, por mucho que pueda despistar el nombre de origen iranio que se les aplica. Dicho término, creemos, puede ser fácilmente explicado como un tecnicismo religioso, en concreto, un término técnico para denominar a los expertos en rituales de ciertas ceremonias mistéricas, posiblemente relacionadas con el dionisismo...

Porém, dentro da literatura filosófica grega, a identificação do mago é mantida com o sábio persa, como um filósofo oriental cuja agudeza não necessariamente estava por baixo da dos helenos. Possivelmente devida a uma tendência "orientalista" presente na Grécia - iniciada timidamente desde o século VIII a.C. ${ }^{9}$ e vigente até passado o helenismo - pode se entender a assimilação da ideia do mago-sábio. Em tal apego, não só o persa foi estimado, senão também as tradições egípcias, hebreias ${ }^{10} \mathrm{e}$ hindus. No que se refere aos persas, Momigliano (1999, p. 201 y 206) afirma:

Indudablemente es tentador explicar ciertos aspectos de los inicios de la filosofía griega a través de las influencias iranias. La repentina elevación del Tiempo a dios primitivo en Ferécides; la identificación del Fuego con la justicia, en Heráclito; la astronomía de Anaximandro, que sitúa a las estrellas más cercanas a la Tierra que a la Luna; estas y otras ideas nos traen a la mente teorías que nos han enseñado a considerar zoroastrianas, o en todo caso persas, o por lo menos orientales... Por extravagantes que se haga aparecer a los persas en Esquilo, no son bárbaros consumados, como los egipcios de Las suplicantes. Más enfático que Esquilo, Heródoto respeta a los persas y los considera capaces de pensar como los griegos ${ }^{11}$

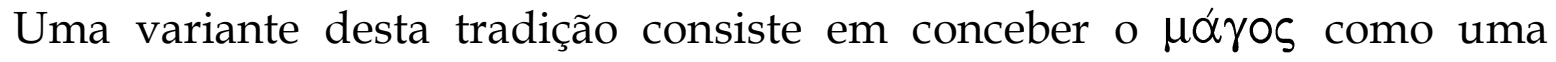
pessoa capaz de operar mudanças extraordinárias no meio ambiente, um

\footnotetext{
${ }_{9}^{9}$ Cf. Feldman (1996). O comentário de Álvarez Pedrosa (2008: 1002) serve para matizar o vínculo político-cultural entre gregos e persas a raiz de diversos fatos históricos: "...suscitaram um interesse singular da cultura persa entre os gregos, que oscilava entre o aborrecimento e a fascinação..."

10 Sobre este particular cf. o capítulo "El descubrimiento helenístico del judaísmo" en Momigliano (1999: 122-155).

11 Álvarez-Pedrosa (2008: 1002-1012) é um pouco menos entusiasta no momento de falar sobre os empréstimos e influencias persas na Hélade, mas não por isso descarta a possibilidade de relações de ida e volta entre ambos os povos. Sua revisão se apega à evidencia linguística rastejável entre textos como os Gāthās e o Avesta, e diálogos platônicos, um pseudo platônico (Axíoco), comedias aristofánicas e laminas órficas. Sobre a dignidade que Ésquilo outorga aos persas Cf. García Novo (2005: 50-53).
} 
iniciado ${ }^{12}$ que conhece segredos muito profundos do universo. As diferentes fontes gregas e romanas adjudicam a distinção de grau nas capacidades dos sábios orientais; desde as que os fazem semideuses, até as mais conservadoras, que os mostram muito perto da filosofia e a liturgia. Eudoxo $^{13}$ e Aristóteles ${ }^{14}$ são talvez os que maior difusão deram a ideia do mago-filósofo.

Fílon de Alexandria (1977, p. XI), comenta sobre os magos:

En el mundo exterior, donde se hallan los que estiman las obras más que las palabras, encontramos amplias asociaciones de la más alta virtud y excelencia. Entre los persas está la orden de los magos, quienes investigan calladamente los hechos de la naturaleza15, a fin de alcanzar el conocimiento de la verdad, y por medio de visiones más claras que el lenguaje, dan y reciben revelaciones de la divina excelencia. En la India, también, existe la orden de los gimnosofistas, que estudian tanto la filosofía ética como la física y hacen de todas sus vidas una exhibición de virtud

Por este caminho segue Apuleio (2003: 26), expressando-se da seguinte maneira:

Magia es en verdad lo que Platón entiende, cuando recuerda qué disciplinas inculcan los persas al niño destinado a reinar. Tengo en la memoria las palabras mismas de este divino varón, que tú Máximo puedes recordar conmigo: Cuando llega a los catorce

\footnotetext{
12 Neste ponto, Álvarez-Pedroza faz de novo uma exortação à prudência histórica, “...os autores costumam considerar que o zoroastrismo é uma religião de iniciados, mesmo que o conceito não se ajuste aos termos mais rigorosos que se dão na religião grega" (2008: 992, N. 4). A magia como iniciação é uma noção que se manteve vigente durante muitos séculos, por exemplo, no Papiro

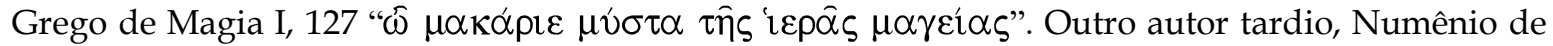
Apameia, incorre num apressamento quando fala da religião do antigo Irã: “...os persas iniciam nos mistérios doutrinando ao iniciado sobre o descenso das almas e sua subida e chamando [este] lugar de caverna. Segundo diz Eubolo, foi Zoroastro o primeiro que consagrou nas montanhas próximas à Pérsia uma caverna natural, florida e regada de fontes, em honra a Mitra, criador e pai de todas as coisas, já que a caverna lhe outorgava uma imagem do mundo, o que Mitra fabricou, enquanto que os objetos no seu interior dispostos a distancias simétricas seriam símbolos dos elementos e zonas do cosmos. Depois do aludido Zoroastro o costume de celebrar suas iniciações em grutas e cavernas, naturais ou artificiais." Fr. 60.

${ }^{13}$ Quem afirmava que os magos eram "a mais excelente e valiosa das seitas filosóficas", além de datar o nascimento de Zoroastro seis mil anos antes da morte de Platão. Cf. Plínio, XXX, 5.

${ }_{14}$ As reconstruções da sua obra Sobre a filosofia recolhem alguns comentários ao respeito: i) que os magos são mais antigos que os sacerdotes egípcios, ii) que há dois princípios regedores do universo: Arimano e Oromasdes e iii) proporciona outras fontes que falam sobre os magos: Hermipio Sobre os magos (este dado se encontra também em Plínio, XXX, 4), Eudoxo Viagem e Teopompo, Filípicas VIII. D.L. I, 8. Sobre a opinião que Aristóteles tinha dos sábios orientais, cabe lembrar que na Metafísica 918b 21-23 fala dos sacerdotes egípcios.

${ }^{15} \mathrm{O}$ sublinhado é meu. Note-se como descreve os magos.
} 
años, reciben al muchacho aquellos que los persas llaman pedagogos reales. Son escogidos en número de cuatro, entre los persas de edad madura que gozan de mejor fama: el más sabio, el más justo, el más prudente y el más valeroso. Uno de ellos le enseña la magia [magei/an] de Zoroastro, hijo de Oromasdes. Ésta consiste en el culto de los dioses. Le enseñan también el arte de reinar. ${ }^{16}$

Mais adiante, Apuleio faz outras referencias à magia e aos magos, e. gr.: em 26 critica a ideia popular que consiste em crer que o mago é omnipotente graças ao uso de conjuros e cânticos dirigidos aos deuses; em 31 alude a uma crença compartida por "muitíssimos" consistente em considerar Pitágoras como seguidor de Zoroastro e destro na magia; em 38 menciona certa crença do seu tempo que vincula os babilônios e egípcios com ensalmos e conjuros; em 40 estabelece com cautela vínculos entre o filósofo, o médico e o mago, sendo o conhecimento da natureza o comum denominador entre os três. Por último, em 90, cita um catálogo de magos eminentes composto por Carmendas, Dardano, Moisés, Iannes, Apolobex, Ostanen e Zoroastro ${ }^{17}$.

Achamos um par de entradas na SUDA, possivelmente influenciadas por tradições neoplatônicas e pitagóricas tardias, nas que se toca o tema dos magos. Em D, 447 se fala sobre Demócrito listando seus mentores: M $\alpha \gamma \omega \hat{\omega} v$

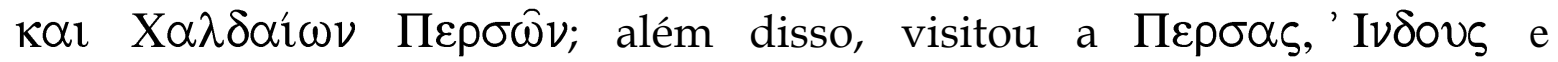

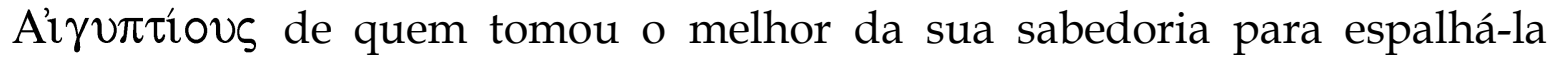
entre os gregos. Em $\zeta$, 159, dedicada a Zoroastro, é definido como um $\sigma 0 \phi o ́ \varsigma^{18} \mathrm{e}$

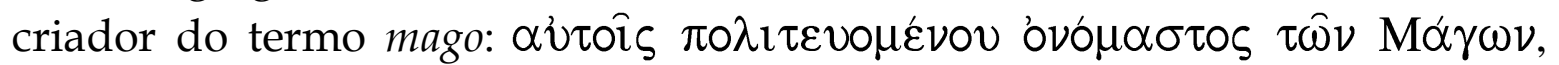
datando sua existência histórica quinhentos anos antes da guerra de Troia.

Os célebres Oráculos caldeus constituem uma fonte importante para compreender a transmissão do termo mago. Neles confluem elementos de um neoplatonismo muito particular com matizes gnósticos e pitagóricos, de forte orientalismo, assim como nuanças de religiões mistéricas gregas, em

\footnotetext{
${ }^{16}$ As palavras citadas de Platão aparecem em grego no meio do texto latino.

17 A propósito do texto de Apuleio, onde se defende contra acusações de ter praticado magia, deve ser mencionado que dentro do egípcio copta o termo нıк, derivado de $h k 3$ passou ao âmbito jurídico greco-romano interpretado como "impius and ilegal sorcery" Cf. Ritner (2001: 321). Cabe

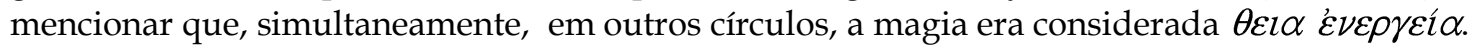

18 Segundo o dicionário bizantino, seu saber destacava especialmente em astronomia, mas seu conhecimento da natureza era muito amplo. Segundo afirma Bremmer (1999: 5), Janto de Lidia foi o primeiro grego que mencionou Zoroastro.
} 
particular o orfismo e os cultos eleusinos. Os Oráculos costumam trasladar o termo $\chi \alpha \lambda \delta \alpha i$ ios com $\mu \alpha \gamma_{\gamma}{ }^{19}$. O primeiro vinculado com tradições babilônicas relativas ao conhecimento físico e espiritual das estrelas, a adivinhação, a interpretação dos sonos e, em alguns casos, com o manejo de ensalmos capazes de alterar o funcionamento da natureza. Segundo a tradição erudita bizantina, foi Juliano o Teúrgo ${ }^{20}$, filho de Juliano o Caldeu $(\chi \alpha \lambda \delta \alpha i ̂ s)^{21}$, quem compilou os célebres Oráculos. O comentário de García Bazán na introdução dos Oráculos caldeus (1991: 14-15) clarifica a visão que então se tinha dos caldeus e os magos:

Los caldeos constituían tanto una agrupación iniciática dirigida por
sus hierofantes, en este caso concreto Juliano el Caldeo, como
practicantes de ritos y conservadores de doctrinas, indicadas por
símbolos orales (los lógia di'epôn o fórmulas versificadas) y físicos,
de naturaleza tradicional, es decir, de origen divino y regularmente
transmitidos, para poder poseer un carácter eficaz o teúrgico. Este
tipo de asociación mistérica está emparentada en su aspecto
litúrgico y en los puntos fundamentales de sus creencias... con los
magos (mágoi) anatólicos de origen medo-persa, una vez
configurada cosmográficamente su doctrina por la ciencia astral
del clero babilonio... Es también común a los miembros de estos
grupos esotéricos la incorporación de rasgos propios de las
prácticas de los magos-caldeos en tierras siríacas (trashumancia
ramificadora y uso de encantos y conjuros), así como la adopción
filosófica de un platonismo difuso, pero de orientación
pitagorizante.

Dado que a Hélade foi uma sociedade viva, temos que entender que o idioma era cambiante e estava em constante movimento, os significados de

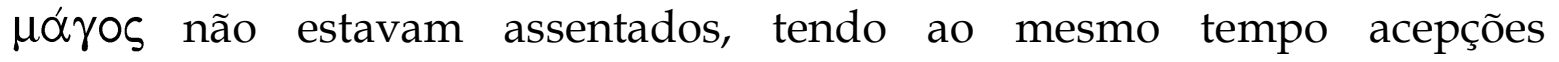
humilhantes e meritórias, seu uso dependendo da comunidade. Numa

\footnotetext{
19 Paralelos com SUDA $\Delta, 447$ ?

${ }^{20}$ Cf. SUDA, 1 434. No artigo se mencionam detalhes que o inserem na tradição orientalizante greco-romana da época, entre o final do Helenismo e o inicio da Antiguidade Tardia. V. gr.: se lhe

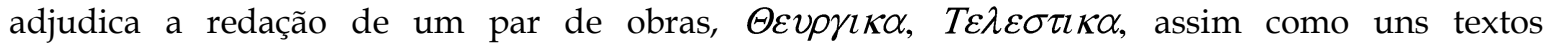

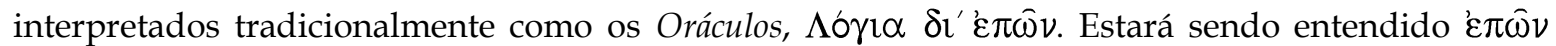
misturando sua conexão com a antiga épica heroica (uma forma de render culto a os mortos) e com os conjuros? Dentro deste mesmo artigo é narrado como Juliano fez chover mediante um saber secreto; porém, também é dito que alguns adjudicavam a Apvovфis, um filósofo egípcio, tal maravilha. De novo aparecem elementos da mentalidade da época, é difícil determinar até que ponto estamos ante uma tendência orientalizante e em que medida se narram fatos e pessoas reais.

${ }^{21}$ Cf. SUDA, 1 433, O Caldeu é definido como filósofo, é mencionada uma obra sua sobre os daimones, composta por quatro livros.
} 
dimensão pejorativa estava vinculado ao yóns (feiticeiro, bruxo, mago 22,

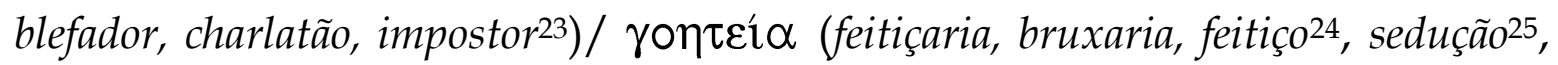
charlatanearia ${ }^{26}$, atração enganosa $\left.{ }^{27}\right)$. Está vinculado também com 'é $\pi \delta \zeta^{28}$ (conjurador, quem canta ensalmos mágicos ${ }^{29}$, saudador) e com $\phi \alpha \rho \mu \alpha \kappa \varepsilon v ́ s$ feiticeiro, preparador de poções, e as práticas por ele desenvolvidas $\phi \alpha p \mu \alpha \kappa \varepsilon i \alpha^{30}$. Máros, mais do que ser um termo cujo sentido foi perdendo seu significado original ao decorrer dos séculos, foi uma palavra que somou conotações, dependendo dos propósitos dos autores. Porém, cabe assinalar que não é tão simples identificar a magia e o mago com a irracionalidade, as tradições populares, crenças supersticiosas ou a charlatanearia sem explicar toda a complexidade que envolve a recepção do conceito nas nossas línguas contemporâneas. $\mathrm{O}$ cristianismo contribuiu significativamente a fixar $\mathrm{o}$ sentido de magia como uma prática pseudorreligiosa contraria aos mandamentos. $\mathrm{O}$ islã, devido a suas raízes cristãs, adota em parte tal

22 Calvo Martínez assinala sobre o termo yóns: “... com frequência serve como insulto, é uma palavra sempre carregada de valores puramente negativos..." (2007, p. 304) Estas três acepções podem ser encontradas na Historia II, 33 de Heródoto; Hipólito, 1038 e Bacantes, 234 de Eurípides; na República, 380d de Platão; em Marco Aurélio Antonino, 1,6; Historia dos animais de Eliano, III, 17; e, Eneadas, IV, 4, 40 de Plotino.

${ }^{23}$ Com estes significados pode ser encontrado no Banquete 203d de Platão. Demóstenes XVIII, 276, nesta passagem utiliza-se o termo $\mu \alpha \alpha \gamma o \zeta$ como sinônimos de $\gamma o ́ n \zeta, ~ t a l v e z$ pela rejeição às importações de impérios hegemônicos como o foi primeiro o persa e depois o macedônio. Na Preparação ao Evangelho V, 18,6 de Eusebio. Num fragmento de um papiro erótico grego, Hermes, 55, 1920,191; em 77/78, 33 de Dío Crisóstomo; em Orações XXVIII, 11 de Aristides, e em Contra Celso II, 49 de Orígenes. Em Édipo rei, 387 pareceria ter dita acepção, mas Clavo Martínez considera que trata-se de uma referência aos magos persas (1999, pp. 308-309).

${ }^{24}$ Cf. Gorgias B 11,10, onde é sinônimo de $\mu \alpha \nu \tau \varepsilon i ́ \alpha$; Banquete 202e e República 582a de Platão; em Crisipo, III, 96, e Eneadas IV , 4, 43 de Plotino.

${ }^{25}$ Cf. República, 413d de Platão; Iambi ad Seleucum, 179 de Anfiloquio e Cartas a Ático, 180, 4 de Cícero.

${ }^{26}$ Cf. Sobre a enfermidade sagrada, XXI, 26, onde é paralela às purificações fraudulentas.

${ }_{27}$ Cf. Eneadas, IV, 44, 4 de Plotino y Stromata, II, 20, 120 de Clemente de Alexandria. Vinculado possivelmente ao termo $\psi \eta \phi о \pi \alpha$ í $\kappa \tau \eta \varsigma$ "prestidigitador", que depois será uma forma de denominar os magos egípcios que Moisés enfrentou.

${ }^{28}$ Deriva do termo ع̌̃⿰o丂, palavra, narração, canto aos heróis.

${ }^{29}$ Dentro da literatura tardia, são encontradas diferentes classes de conjuros, $\dot{\varepsilon} \pi \delta \eta$, ou seja: para afastar um mal, PGM XX, 5 e 13; ensalmo para pedir a intervenção de um deus através de um daimon, PGM, I, 296 e 317, feitiço com fins eróticos, PGM, IV, 295, VII, 992 y XX, 3.

30 Sobre este termo, Kingsley (2008, p. 295) comenta: “...a palavra pharmakon possuía também a acepção de "encantamento", e no caso do fragmento empedocleu [Diels, III] designa os remédios, mas também, de modo implícito, os conjuros ( $\varepsilon \pi \delta \alpha$ i) que eram recitados durante a preparação de

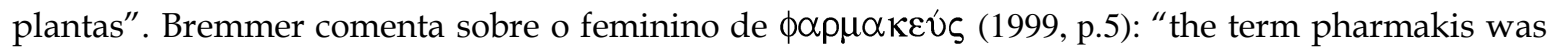
probably once limited to a woman who collected herbs for magic, but gradually in must have absorbed (or: benn ascribed) qualities from the male sorcerers". 
concepção ${ }^{31}$; em árabe سحر (sḥr), magia, reúne as acepções pejorativas expostas. Contudo, existe uma aleya que nos convida a colocar atenção especial na transmissão do conceito:

Siguen lo que practicaron los demonios en el reinado de Sulayman. Pero no fue Sulayman quien cayó en la incredulidad, sino que fueron los demonios al enseñar a los hombres la magia que le había sido revelada a los dos ángeles...

A magia constitui o saber de mistérios que não podem ser revelados ao homem, quando isto acontece é cometida uma transgressão dos limites impostos por Allāh; o sufismo, por outro lado, contempla o conhecimento moderado de ditos secretos. As observações de Ibn Jaldún sobre o tema servem para clarificar parte da interpretação da سحر dentro do islã. Afirma (2011: 927)

\begin{abstract}
"los hombres de sólida inteligencia jamás han tenido la menor duda respecto a la existencia de la magia. Han advertido los efectos que ella produce... [empero] La ley divina no hace ninguna distinción entre la magia, el arte talismánico y sus respectivos influjos; todo lo incluye dentro de las cosas proscritas. (p. 933)." La excepción la constituyen los sufistas, quienes "...por un don de Dios, desarrollando la facultad de ejercer una influencia sobre las cosas del mundo, influencia que no debe confundirse con la magia [porque ésta es animada por los demonios] (p. 932)")32
\end{abstract}

Poderíamos aventurar, então, uma distinção entre magia negra e "magia branca".

\footnotetext{
${ }^{31}$ No Corão podem ser encontradas diversas aleyas em que a magia é vista como charlatanice ou prestidigitação, por exemplo: VI, 8, VII 108, 111 e 115 se joga com os sentidos do termo desde o maravilhoso até a prestidigitação. X, 77, XI, 7, XX,56, XXI, 3, XXV, 8, XXVI, 33 e 34, 36 e 37, 39 y 40, 45; XXVII, 13, XLIII, 29, LI, 39, LII, 13, LIV, 2, LXI, 6 e LXXIV, 24.

32 A seção VI, 22 de Al-Muqaddimah está dedicada a desacreditar a magia demoníaca, exibindo-a como uma prática que se vale de talismãs e cujas fontes podem ser a manipulação maligna, a prestidigitação ou a persuasão psicológica. Também é importante assinalar que Ibn Jaldún identifica os caldeus, assírios e coptas como os praticantes da talismânica da Antiguidade.
} 
Um dos aspectos mais importantes que temos que ter em conta para abordar o pensamento egípcio é assumir que carecemos das categorias culturais que consigam captar com total precisão a natureza de tradições e práticas tão arraigadas. É frequente prejulgar aos egípcios, apelidados de ser extremamente religiosos, ao extremo de professar uma superstição ingênua. Chega-se a defini-los como pragmáticos sendo o contrario da mentalidade grega dedicada à teorização. Para iniciar o exercício de tradução cultural, quisera evocar o caso do olimpismo citado páginas anteriores. Aceitaríamos que fosse classificado por estudiosos forâneos só no campo dos negócios, da política, da tecnologia? Na verdade, é uma mistura de tudo, lograda no contexto de um mundo "democrático" e "livre". Da mesma maneira, devemos atuar com prudência ao falar do antigo Egito, mesmo suas matemáticas e liturgia parecendo similares às nossas, é preciso compreendêlas no marco em que se deram. Wieleitner (1927: 13) questiona nosso entendimento da "ciência" egípcia:

Wenn man die Wissenschaft der alten Ägypter als "praktisch" oder "rein empirisch" hinstellt, wird man in vielen Fällen natürlich nicht Unrecht haben. Jedoch scheint mir damit meist ein Unterton des Herabsetzenden verbunden zu sein, den ich nicht für berechtigt halte

Se algo tão próximo a nossa mentalidade ocidental tem problemas na hora de ser enquadrado com precisão na sua dimensão original, maior será a complexidade para entender a 1 Para começar, considero pertinente concretizar que não existe uma palavra em egípcio hieroglífico que corresponda a o que nós entendemos por magia 33 , assim como tampouco existia um paralelo da $\mu \alpha \gamma \varepsilon i ́ \alpha$. O vocábulo contém dois componentes que seria útil revisar.

\footnotetext{
${ }^{33}$ Existia vocabulário de "expressões mágicas", por exemplo l um deus, criticar.

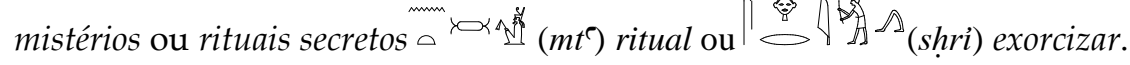




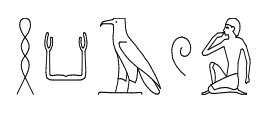

12

1) $k 3$ : braços, possivelmente em gesto de louvor, conectados com a ideia de adoração, talvez até algo próximo à contemplação; mas, também, com uma "energia espiritual pessoal-cósmica". Betrò comenta:

...eine Lebenskraft, die sowohl Menschen wie Götter besitzen. Er überträgt sich vom Vater auf den Sohn und gehört, da er mehr ist als ein Element der individuellen Persönlichkeit." (2004, p. 58)34

2) determinativo que tem a ver com atividades vinculadas com a boca: falar, calar, beber, comer, contar. Também relacionado semanticamente com aspetos relativos ao pensamento e ao gosto. No caso da $h k 3$ parece relacionada com pronunciar conjuros, sem deixar de lado o aspecto cósmico que os fundamenta e valida. Em TdP achamos uma frase que reflete o poder do conjuro: "Whenever I speak to you, gods, you see and hear my speech." (Parede norte, antecâmara, 753).

É frequente que se estabeleçam vínculos apressados identificando sem mais um conjuro ou um exorcismo com a $h k^{3}{ }^{35}$. Ritner (2001, p. 321-336) aponta algumas acepções que facilitam a tradução cultural: i) "force that once animated, compeled, and protect the gods and subsequent creation ${ }^{36}$. Antecedent to the creative word $(\mathrm{Hu})[8-1, \mathrm{~h} u)]$. Heka infuses the creator's projected images or ka-spirits, with his "magical" vitality" 37.

Em ocasiões é personificada38, um exemplo muito claro é LdM 84: Faulkner traduz: "I don't know the magician, but I hear his words", as seguintes

\footnotetext{
${ }^{34}$ A $h k 3$ também constituía um fator para definir a identidade da pessoa, assim pode ser visto em Textos das Pirâmides TdP, Unis, corredor - paredes oeste e leste, 316; TdP, Pepi I, parede oeste da antecâmara, 472; TdP, Pepi I, parede sul do vestíbulo, 539.

${ }^{35}$ Hans Fischer, no seu estudo introdutório aos textos mágicos egípcios (2005: 9), comenta sobre o problema para interpretar a "magia egípcia": "Im Deken der Alten Ägypter hat der Demiurg seinen Geschöpfen neben anderen elementaren Dingen wie Luft, Nahrung, Himmel und Erde sowie einem Königtum als ägyptisch hekaw und im späteren Koptisch hik lautet. Diesen Begriff übersetzen wir Modernen leichtfertig, wie "Zauber" oder "Magie", ohne dabei zu bedenken, wir sehr westlichem Deken klassisch-antiker und besonders jüdisch-christlicher Prägung verpflichtet sind"

${ }^{36} \mathrm{Cf}$. TdP, Teti, câmera funerária, 324.

37 Cf. Textos dos sarcófagos, 261.

38 A propósito da personificação da $h k$, alguns deuses eram identificados com o epíteto "O Grande da $h k$ '?" ou "O Grande Mago" (wrt- $h k 3$ s), regularmente eram Seth e Horus os que recebiam tal titulo, mas não eram os únicos. Cf. TdP, câmera funerária, lado sul 220, 222; Pepi I, extremo oeste da
} 
versões coincidem na ideia central: Budge: "I know Heka, I hear his words", Lara Peinado "No conozco (tampoco) a Heka, (si bien, solamente) oigo sus palabras mágicas", Barguet: "no conozco a Heka, oigo (solamente) sus palabras mágicas". A ḥk 3 está composta, segundo, Ritner, por três elementos constitutivos: a fala (conjuro), as propriedades inerentes ${ }^{39}$ (compreensão do ente e as condições que o rodeiam, uma das possibilidades do $k 3$ ?) e o rito (ato de vinculação com os princípios que regem o cosmos). Talvez seja esta uma das interpretações que mais nos interesse, pois aqui está impresso um projeto cósmico, podendo ter conexões com nossa ideia de estética (Teoria da Harmonia) e metafísica (Teoria sobre a Realidade). O projeto cósmico está marcado por $(M 33 t)^{40}$, síntese de ordem expressado na legalidade, a beleza, a saúde e o equilíbrio. De tal forma que a $h k 3$ não é um principio sobrenatural arbitrário, tendo que se adaptar às proporções e ritmos que regem a Realidade. Allen, no seu léxico comentado TdP, assinala: "The term $h k 3$ generally refers to the force itself, while $h k 3 w$ [mago] denotes the medium through wich the force is excersised, usually "magic spells" (2015: 360). ii) Rituais e conjuros que tinham como objetivo alterar o ordem das coisas, destruir inimigos ${ }^{41}$, alterar a aparência para evadir os ataques de gênios no Além $^{42}$ ou atrair ao ser desejado ou amado ${ }^{43}$. O anterior era só uma de tantas aplicações que podia ter a força neutral $h k$ s, ou seja, não existia uma concepção de magia negra o branca. A maioria dos textos que plasmam

câmera funerária, 443; TdP, Merene, extremo oeste da câmera funerária, 592. - Em Pepi II, na parede norte da antecâmara, 692 B Thot é chamado "Senhor da Magia".

${ }^{39}$ James (2001: 76) afirma a respeito: "The Doctrines of the universal distribution of the atoms, and their emanation from external objects are derived from magic: These doctrines are magical and express the magical principle "that the qualities of animals or things are distributed throughout all their parts".

40 Para ter uma perspectiva mais clara de M33t, Cf. LdM, 15 (vinculada à magia como poder protetor), 31 (ritmo), 39 (destruição), 41 (justiça), 50 (criação do mundo), 79 (purificação moral do defunto), 130 (equilíbrio integral do individuo), 145 y183 (justiça e verdade), 165 "País de M33t," (o Além, terra dos justos).

${ }^{41}$ Conservamos um volume importante de textos destinados a afugentar animais perigosos. Para seguir alguns exemplos: Fórmula contra cobras, conjuros 226, 228 e $230 \mathrm{TdP}$, Unis. Fórmula contra serpentes, contida no P. de Turim 54003, conjuro III (ca. 2000). O P. do BM 9997 contem conjuros contra serpentes que devem ser utilizados com um amuleto de faiança. Existe uma imagem disponível do papiro em: http://www.britishmuseum.org/research/collection_online/collection_object_details.aspx?objectI $\mathrm{d}=113679 \&$ partId=1\&searchText=papyrus+9997\&page=1 . No P. de Harris BM EA 10042, 4-9, ao final de um hino percebe-se a complexidade para classificar os textos dentro de nossas categorias literárias; aparece um ensalmo que afugenta crocodilos do rio e leões do deserto.

42 Isto fez com que alguns estudiosos pensassem que os egípcios acreditavam na reencarnação em organismos animais.

43 Por exemplo, um conjuro de amor escrito no óstrakon Deir el Medina 1057 (ca. 1100 a.C.). 
rituais e ensalmos datam de época tardia44, o que torna muito difícil saber com certeza a maneira em que se deu a fixação de tradições ancestrais em suportes materiais. iii) Emanação de Ra $(b 3 w)$ que acompanhava atividades como a agricultura, a medicina, os rituais de estado, a arquitetura (fundação de cidades e ereção de construções). iv) a funerária aplicada na conservação de cadáveres por médio do embalsamamento composto por um momento material e outro de processos "espirituais", "sobrenaturais", "divinos". O sacerdote funerário recitava ensalmos e conjuros enquanto tratava o cadáver com elaborados métodos de preservação que envolviam saberes que hoje localizaríamos na química, a biologia ou a medicina ${ }^{45}$. O corpo mumificado era, segundo a mentalidade egípcia, a herança sagrada obsequiada pelos deuses -particularmente por Osíris-; era, arriscando cometer uma transgressão cultural, o mistério por excelência que dava significado a rituais e pensamentos egípcios. Num trecho dos TdP (câmera funerária de Unis, lado sul, 213, achamos um conjuro que envolve a consagração do corpo

Ho, Unis! You have not gone away dead: you have gone away alive. Sit on Osiris' chair, with your baton in your arm, and govern the living with your lotus scepter in your arm, and govern those of the remote places.

Your lower arms are of Atum, your upper arms of Atum, your belly of Atum, your back of Atum, your rear of Atum, your legs of Atum, your face of Anubis46

44 E. gr.: o Papiro Bremner Rhind, pertencente a BM, EA 10188, 17 (Cantos de Isis e Neftis) datado de 350 a.C., pode ser consultado através de https://www.britishmuseum.org/research/collection_online/collection_object_details.aspx?object

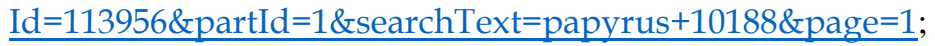

${ }^{45}$ Budge (1988: 185) comenta ao respeito: "But for an account of the manner in which the body was bandaged, and the list of unguents and other materials employed in the process, and the words of power which are spoken as recourse to a very interesting papyrus which has been edited and translated by M. Maspero under the title of Le Rituel de l'Embaumement. The first part of the papyrus, which probably gave instructions for the evisceration of the body in wanting..." -Em TdP Unis, parede leste, 273-274 se fala em ingerir a $h k 3$ como uma das coisas que devem ser feitas pela pessoa que pretenda ser imortal no Além.

${ }^{46}$ Uma consagração do corpo mais detalhada pode ser vista em LdM, XLII: "My hair is Nun; my face is Re; my eyes are Hathor; my ears are Wepwawet; my Nose is She who presides over her lotus-leaf; my lips are Anubis; my molars are Selket; my incisors are Isis the goddess; my arms are the Ram, the Lord of Mendes; my breast is Neith, Lady of Sais; my back is Seth; my phallus is Osiris; my muscles are the Lords of Kheraha; my chest is He who is greatly majestic; my belly and my spine are Sakhmet; my buttocks are the Eye of Horus; my thighs and my claves are Nut; my feet are Ptah; my toes are living falcons; there in no member of mine devoid of a god, and Thot is the 
v) Um sentido implícito que tinha a $h k 3$-conjuro, é o de ser uma espécie de historia oral na que se recolhem evidencias da relação com povos estrangeiros ou de um léxico obsoleto conservado em expressões ininteligíveis que revestem de misticismo as palavras do mago. Lewis Spence (1990: 265) comenta:

\begin{abstract}
A great many of these seemingly nonsensical spells consist of foreign words and expressions, some of them of Syrian origin. It is well know that the shamanistic class in savage communities is prone to invent a secret language or dialect of its own, and that the vocabulary of such a jargon is usually either archaic or else borrowed from the neighbouring language47
\end{abstract}

vi) Os conjuros como terapia médica. ${ }^{48}$ Suponhamos que os egípcios acreditavam na efetividade dos conjuros; porém, se especula quando são reduzidos a mera superstição. Segundo os registros conservados, a palavra mágica acompanhava aos procedimentos médicos em casos como mordedura de ofídios, padecimentos da matriz ou no combate à infertilidade. Era frequente também que fosse empregada em padecimentos psicossomáticos ou em outros não muito bem conhecidos, como as pestes ${ }^{49}$.

protection of all my flesh." Em TdP, Pepi I, parede sul do vestíbulo, 539, achamos um conjuro similar.

${ }^{47}$ Conservamos diversos textos egípcios nos quais aparecem palavras que os estudiosos não logram decifrar, termos que caíram em desuso ou são, possivelmente, parte de um "léxico mágico" cuja etimologia remonta-se a idiomas arcaicos. No P. de Leiden I, 348, 4,1 é mencionado um tecido nedj, em 8,6 se fala do sangue do peixe 3bdju. No P. BM 10059, 5 (ca. 1200 a.C.) podemos ler o seguinte: "Beschwörung der Asiaten(krankheit) bestehend aus dem, was Kreta dazu (=zur Beschwörung) sagt: s-n-t-k-p-p-w-y-j-y-m-n-t-r-k-k-r". O papiro pode ser consultado na seguinte página: http://www.britishmuseum.org/research/collection_online/collection_object_details/collection_i mage_gallery .aspx?assetId $=35790001 \&$ objectId $=110335 \&$ partId $=1$. No LdM aparecem vários nomes mágicos (secretos) dos deuses, por exemplo 165, 166, 167. No P. BM 9997, VI 2, aparece mencionada uma serpente de nome schepu-ib. No P. Edwin Smith XXI, 9 é mencionada a fruta hm3yt que não pode ser identificada. Nos seus comentários, Breasted sugere que pode ser uma noz (p. 496). No mesmo texto, em XX, 8 é mencionada a planta $\breve{s} m s$. Em TdP, Teti, parede leste da antecâmara, 377 se fala da serpente $h p j w$ e se identifica o defunto com uma força chamada $\underline{d}^{\top} \mathrm{m} w$, 382-383. Em TdP, Pepi II, extremo leste da câmera ritual, 180-191, contém uma serie de palavras mágicas para nomear vasilhas e pães.

${ }^{48}$ Cf. P. de Leiden I, 348, 3,8-8,7. (ca. 1200 a.C.) onde se compendiam quatro conjuros contra a enxaqueca e um exorcismo para tirar os demônios que atormentam ao paciente. No P. de Atenas 1826, 7,11-8,5 (ca. 1200 a.C.) recolhe-se um conjuro contra uma "enfermidade estrangeira e demônios", possivelmente um tipo de peste; assim como dois ensalmos para ser pronunciados com amuletos, destinados a resolver o mesmo padecimento.

${ }^{49}$ No P. Edwin Smith há uma pequena seção (XVIII-XX) integrada por oito encantamentos (exorcismos) contra a peste do ano, destinados a combater o vento maligno, uma espécie de peste periódica que cada ano voltava a causar estragos entre a população. Poderíamos estar diante de

Revista Heródoto, Unifesp, Guarulhos, v. 2, n. 1, Maio, 2017. p. 183-211 - 204 - 
Os facultativos egípcios sabiam reduzir fraturas, fazer cirurgias e prescrever remédios com base na farmacopeia; sua prática não tinha os avanços tecnológicos que hoje temos, mas não por isso podemos considerar que suas terapias pecavam de credulidade ou preguiça mental.

\section{A título de conclusão}

Considero que a atitude mais pertinente que podemos ter com respeito à é mantê-la apegada ao contexto onde surgira. Colocá-la na nossa escala evolutiva do pensamento, num degrau abaixo da religião, é atentar contra sua unidade originaria. Contudo, ao fazer uma tradução cultural, cabe a possibilidade de achar pontos de coincidência com nossa ideia de filosofia, sem reduzi-la a ela. A $h k$ j estava constituída a partir de uma axiologia que não é compatível com a ocidental, não porque constitua um abandono à reflexão crítica do mundo, senão porque seus propósitos básicos partem de uma sensibilidade diferente ${ }^{50}$. James (2001, p. 103) considera: "Magic is the key to the interpretation of ancient religions and philosophy'. E continua

...since it was the method of the Egyptians to conceal the truth by the use of myths, parables, magical principles (primitive scientific method), number philosophy and hieroglyphics, we can easily see what methods might be involved before we could arrive at better translation of the Memphite Theology" (p. 147)

purificações coletivas, "medicina social"?, profilaxia, higiene em seu sentido etimológico mais distante?

50 Egipto, al igual que otras grandes civilizaciones de la Antigüedad no puede ser limitado a un puñado de aspectos culturales ni a una tipología racial única. Existía un Egipto negro, uno con raíces en Anatolia, otro mediterráneo, constituyendo cada uno un pequeño universo en miniatura. Respecto del Egipto negro, y, en general de la negritud africana, el ensayo de Souleymane Bachir Diayne (2011) nos invita a pensar en la estructura que guía mentalidades distintas a las nuestras. "...the expression of African philosophy itself, that is to say, the way of seeing, thinking and feeling that integrates fields of human activity as different as medicine, law, religion, logic and wisdom by serving as raison d'être and the key to truly understanding them. Among these fields, artistic activity is primary, even before religion: because, where orality reings, art constitutes the writing which allows us to read the metaphysics it transcribes" (p. 54). E aqui cita umas palavras de Sénar Senghor: "What is rhythm? Is the architecture of being, the internal dynamism that gives it form, the system of waves it gives off toward Others, the pure expression of vital force. Rhythm is the vibrating shock, the power which, through the senses, seizes us at roots of our Being. It expresses itself through the most material and sensual means: lines, surfaces, colors, and volumes in architecture, sculpture and painting, accents in poetry and music; movements in dance. But it doing this, it organizes all this concreteness toward the light of the Spirit. For the Negro African, it is insofar as it incarnate in sensuality that rhythm illuminates the Spirit." (pp. 78-79) 
Desde sua criação na Hélade, a palavra "magia" é insuficiente. Primeiro para captar o que faziam os persas, depois ao ser aplicada à -1 in com uma forte carga de platonismo pitagorizante. É preciso reconsiderar o papel que joga um esquema tão complexo dentro da estrutura multicolor dos povos antigos. Podemos ou não estar de acordo com os prolegomenos que apoiavam esta manifestação cultural, mas vale a pena estudar algo que esteve tão presente naqueles séculos.

Ao estudar o pensamento egípcio na procura de filosofia, normalmente são tratados os mesmos temas ${ }^{51}$. Não se chega além de uma revisão das cosmogonias, impressas nas teologias chegadas até nós. O denominador comum está em localizá-las no terreno da religiosidade exagerada e, nos casos mais moderados, qualifica-las de presciência, prefilosofia ou pensamento racional embrionário. Porém, conceitos como Lã simplificados ao âmbito religioso sem abrir a possibilidade de chegar perto dos fundamentos que os articulavam. Asante (2000: 1-2) revisa com atenção os prolegômenos do pensamento nilótico:

It is not trite for the African to say: "everything is everything". And to the mind of the ancient Kemetic [Egyptian] people this idea was thought to represent the whole universe as one. From the beginning it was oneness of everything that became the key with which the Egyptian mind unlocked many secrets of the world. Thus, one's world, whether from the personal or the collective perspective, was based upon the actual quest to make the world one, to establish the interconnections of all things, to reconstruct the universe as it was in the beginning" (pp. 2-3)

Qualquer texto ou discurso que seja estudado isoladamente conduzirá a uma visão distorcida de seus autores. As reputadas Críticas de Kant, os escritos de fenomenologia de Hursserl ou as meditações de Antonio Machado não estão isentas de tais leituras. Qualquer escrito pode ser reduzido a "mera literatura" letra muerta - segundo o giro depreciativo que tem dado alguns filósofos contemporâneos à expressão. Os conjuros egípcios são o branco de tal simplificação; ainda assim a só compusera por ditas peças, mereceria um tratamento mais completo e tolerante. Frequentemente se perde de vista que as "palavras mágicas" pertenciam a um complexo sistema de ideias do qual o divino, o natural e o humano

${ }^{51}$ Hornung (2000: 113-115) é dos poucos egiptólogos que revisa com maior detalhe a essência e historiografia do pensamento egípcio. 
conviviam estreitamente. Um esquema de ideias que deveria considerar-se tão digno como o produzido por Platão e Aristóteles, só que delimitando as claras diferenças que os distinguem. Para nossa mentalidade significa um esforço tiânico imaginar que existem outras maneiras de pensar, equipadas com outros cimentos e propósitos. Aqui surge a pergunta incômoda: quão plural é a nossa filosofia?

Por que não empreender um exercício de tradução cultural como o que tem

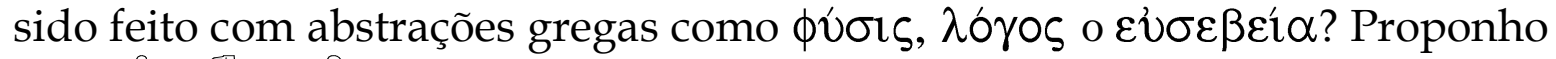
que a possua o qualificativo de a-filosófica, por ter uma natureza diferente a nossas ideias de filosofia e evitando atitude de "dignifica-la". Isso não implica que tal questão coloque na mesa reflexões essenciais, como as ideias de unidade, existência, divindade, humanidade - condição de ser humano - ou linguagem. Nessas coordenadas é para onde devemos dirigir nossa atenção.

Apêndice: línguas faladas pelos persas.

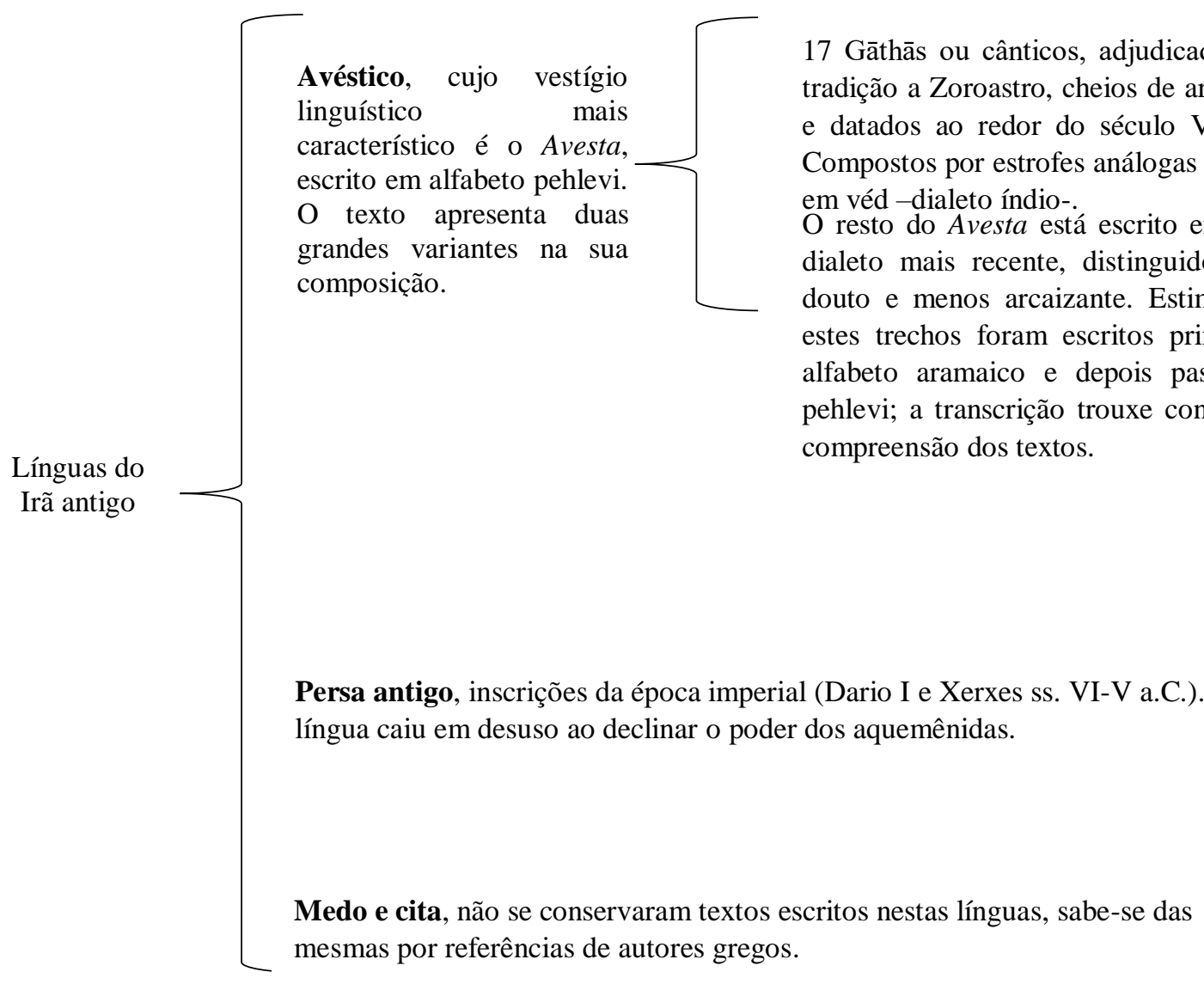

Para maior informação vide Adrados, Bernabé, Mendoza (1995: 108-110) 


\section{Bibliografía}

ADRADOS, Francisco; BERNABÉ, Alberto; MENDOZA, Julia. Manual de lingüística indoeuropea, Tomo I. 1 ed. Madrid: Ediciones Clásicas, 1995, 402 pp. ALTÄGYPTISCHE DICHTUNG. Traducción de Erik Hornung. 1 ed. Stuttgart, Reclam, 2006, 189 pp.

ALTÄGYPTISCHE ZAUBERSPRÜCHE. Traducción de Hans Fischer Elfert. 1 ed. Stuttgart, Reclam Verlag, 2005, 187 pp.

ÁLVAREZ-PEDROSA NÚÑEZ, Juan Antonio. “Muerte, tránsito del alma y juicio particular en el zoroastrismo en comparación con textos órficos." En BERNABÉ, Alberto; CASADESÚS, Francesc (coordinadores). Orfeo y la tradición órfica: II Un reencuentro. Madrid. Akal, 2008, pp. 991-1013.

THE EGYPTIAN BOOK OF THE DEAD. Edición interlineal egipcio-inglés, traducción de Wallis Budge. 3 ed. Nueva York, 2006, 377 pp.

THE ANCIENT EGYPTIAN BOOK OF THE DEAD. Traducción de Raymond O. Faulkner. 1 ed. Nueva York, 2005, 223 pp.

THE ANCIENT EGYPTIAN PYRAMID TEXTS. Traducción de James P. Allen. 2 ed.. Atlanta: Society of Biblical Literature, 2015, 381 pp.

ANTIKE ZAUBERSPRÜCHE. Traducción de Alf Önnerfors. 1 ed. Stuttgart: Reclam Verlag, 1991, 72 pp.

APULEYO. Apología o discurso sobre la magia en defensa propia. Edición bilingüe latín-castellano, traducción de Roberto Heredia Correa. 1 ed. México: UNAM, 2003, 135 pp.

ARISTÓTELES. Fragmentos. Traducción de Álvaro Vallejo Campos. 1 ed. Madrid: Gredos, 2005, 499 pp.

ASANTE, Kete Asante. The Egyptian Philosophers: Ancient African voices from Imhotep to Akhenaten.1 ed. Chicago: African-American Images, 2000, 126 pp.

BETRÒ, Carmela. Heilige Zeichen. Traducción de Christiane von Bechtolsheim. Köln: Marixverlag, 2004, 251 pp.

BREMMER Jan. "The birth of the term 'Magic'". Zeitschrift für Papyrologie und Epigraphik. Bonn, Rudolf Habelt GmbH, Band 126, 1999, pp. 1-12. 
BUDGE, Wallis. Egyotian Magic. 1 ed. Londres: Arkana, 1988, 234 pp.

BURKERT, Walter: De Homero a los magos: La tradición oriental en la cultura griega. Traducción de Xavier Riu. 1 ed. Barcelona: El Acantilado, 2002, 172 pp.

CALVO MARTÍNEZ, José Luis. “¿Magos griegos o persas? Los usos más antiguos del término magos: Heráclito, Sófocles, Eurípides y el Papiro Derveni". MHNH, Revista Internacional sobre Magia y Astrología Antiguas. Malaga: Editorial Canales Siete, Vol. 7, 2007, pp. 301-314.

CONFUCIO: Analectas. Traducción de Alonso Colodrón. Madrid: EDAF, 1998.

CHEN Yong, ¿Es el confucianismo una religión?: La controversia sobre la religiosidad confuciana, su significado y trascendencia. México: El Colegio de México, 2012.

THE EDWIN SMITH SURGICAL PAPYRUS: TRANSLATION AND COMMENTARY, VOL. 1. Traductor James Henry Breasted. 1 ed. Chicago: The University of Chicago Oriental Institute Publications, 1930, 596 pp.

THE EGYPTIAN BOOK OF THE DEAD: (PAPYRUS OF ANI). Traducción y transliteración de Wallis Budge. Edición bilingüe egipcio jeroglífico-inglés. Nueva York: Dover Books, 377 pp.

FELDMAN, Louis. "Homer and the Near East: The Rise of the Greek Genius". The Biblical Archeologist, Vol. 59, No. 1 (Mar. 1996). The Oriental Schools of Oriental Research, 1996, pp. 13-21.

FILÓN. Todo hombre bueno es libre. Traducción de Francisco de P. Samaranch. 2 ed. Buenos Aires: Aguilar, 1977, 86 pp.

FISCHER-ELFERT, Hans. "Two Oracle Petitions adressed to Horus-Khau with some notes on the oracular amuletic drecrees". The Journal of Egyptian Archaeology, Vol. 82. Egyptian Exploration Society, 1996. Pp. 129-144.

GARCÍA NOVO, Elsa. "Las dos caras del protagonist en Los Persas de Esquilo". Cuadernos de Filología Clásica, Estudios Griegos e Indeuropeos, No. 15, 2005. UCM, pp. 49-62. 
DIE GOLDENEN WEISHEITEN VON ZARATHUSTRA. Traducción y compilación de Aria Homayoun. Edición bilingüe farsí-alemán. Berlín: Gardoon Verlag, 2012, 156 pp.

HERÓDOTO, Historia: Libros I y II. Traducción de Carlos Schrader. Madrid. Gredos, 2000.

HERÓDOTO, Historia: Libros III y IV. Traducción de Carlos Schrader. Madrid. Gredos, 2000.

HORNUNG, Erik. Introducción a la egiptología: Estado, métodos, tareas. 1 ed. Traducción de Francesc Ballesteros. Madrid, Trotta, 169 pp.

IBN JALDÚN, Introducción a la historia universal. Traducción de Elías Trabulse. México. FCE, 2011.1164 pp.

JACOBY, Felix. Die Fragmente der griechischen Historiker: Continued. Part four, Biography and Antiquarian Literature. Edición de Guido Schepens. Leiden: Brill, 1998, 392 pp.

JAMES, George, Stolen legacy. Estados Unidos. African American Images, 2001. 191 pp.

JOHNSON Sarah; GAGER John; HIMMELFARB Martha; MEYER Martin; SCHMIDT Brian; FRANKFURTER David; Graf Fritz. "Magic in the Ancient World". Numen. Leiden. Vol. 46, No. 3, 1999, pp. 291-325.

KINGSLEY, Peter: Filosofía Antigua, misterios y magia: Empédocles y la tradición pitagórica. Traducción de Alejandro Coroleu. 1 ed. Girona: Atalanta, 2008. 564 pp.

LÜTH Paul. Die japanische Philosophie. Tübingen: J.C.B. Mohr, 1944.

LIBRO DE LOS MUERTOS. Traducción de Federico Lara Peinado. 2 ed. Madrid: Tecnos, 1993. 401pp.

EL LIBRO DE LOS MUERTOS DE LOS ANTIGUOS EGIPCIOS. 1 ed. Traducción de Paul Braguet. Traducción al castellano de Ramón Alfonso Díez Aragón y Ma. Del Carmen Blanco Moreno. Bilbao. Desclee, 2000, 308 pp.

MARTÍN HERNÁNDEZ, Raquel. “Literatura mágica y pseudocientífica atribuida a Orfeo". En BERNABÉ, Alberto; CASADESÚS, Francesc 
(coordinadores). Orfeo y la tradición órfica: I Un reencuentro. Madrid. Akal, 2008, pp. 437-458.

-------.-. "Ritual órfico y acciones mágicas". En BERNABÉ, Alberto; CASADESÚS, Francesc (coordinadores). Orfeo y la tradición órfica: I Un reencuentro. Madrid. Akal, 2008, pp. 801-814.

MOMIGLIANO, Arnaldo. La sabiduría bárbara: los límites de la helenización. Traducción de Gabriela Ordiales. 2 ed. México, FCE, 1999, 280 pp.

MUÑOZ DELGADO, Luis. Léxico de magia y religión en los papiros mágicos griegos. 1 ed. Madrid: CSIC, 2001, 183 pp.

ONFRAY Michel. Las sabidurías de la antigüedad: Contrahistoria de la filosofía, I. Traducción de Marco Aurelio Galmarini. 1 ed. Barcelona: Anagrama., 2013, $330 \mathrm{pp}$.

ORÁCULOS CALDEOS/ NUMENIO DE APAMEA: FRAGMENTOS Y TESTIMONIOS. Traducción de Francisco García Bazán. 1 ed. Madrid: Gredos, 1991. 312 pp.

SUDA ON LINE: http:/ / www.stoa.org/sol-bin/search.pl

RITNER K. Robert. "Magic". The Oxford Encyclopedia of Ancient Egypt. New York, 2001. Pp. 321-336.

SPENCE, Lewis: Ancient Egypt: Myhts and legends. 1 ed. Nueva York: Dover, 1990, 369 pp.

Wieleitner Heinrich: "War die Wissenschaft der alten Ägypter wirklich nur praktisch?" Isis, The University of Chicago Press. No. 1, Vol 9, pp. 11-28. 